\title{
Andrew Dobson: trajectories of green political theory Interview by Luc Semal, Mathilde Szuba and Olivier Petit
}

\author{
Andrew Dobson ${ }^{1}$, Luc Semal ${ }^{2}$, Mathilde Szuba ${ }^{3}$, Olivier Petit ${ }^{4}$ \\ 1 Professor of politics, Keele University, School of Politics, International Relations and Philosophy (SPIRE), Keele, Staffordshire \\ ST5 5BG, United Kingdom \\ 2 Political scientist, Muséum national d'Histoire naturelle, UMR7204 Cesco, 75005 Paris, France \\ 3 Sociologist, Université Paris 1-Panthéon-Sorbonne, EA2483 Cetcopra, 75005 Paris, France \\ 4 Economist, Université d'Artois, UMR8019 Clersé CNRS-Université Lille 1, 59655 Villeneuve-d'Ascq, France
}

Andrew Dobson, né en avril 1957, est professeur de science politique à l’Université de Keele (Royaume-Uni). Il est reconnu comme l'une des figures principales du courant de la green political theory. Il est l'un des coéditeurs fondateurs de la revue Environmental Politics. Parmi ses principaux ouvrages, mentionnons Green Political Thought (Unwin Hyman, London, 1990, plusieurs rééditions chez Routledge depuis 1995), Justice and the Environment: conceptions of environmental sustainability and dimensions of social justice (Oxford University Press, Oxford, 1998), Citizenship and the Environment (Oxford University Press, Oxford, 2003). L'entretien réalisé en novembre 2012 permet de revenir sur son itinéraire et sur son positionnement particulier au sein de la green political theory - vis-à-vis des approches traditionnelles en science politique pratiquées outre-Manche. La question de la place et du rôle des recherches interdisciplinaires dans le parcours d'Andrew Dobson est également abordée. Par ailleurs, compte tenu de l'investissement d'Andrew Dobson dans la sphère politique britannique (il est l'un des deux auteurs du manifeste du Green Party publié en 2010, et le sera à nouveau pour 2015), l'entretien revient sur les liens entre science et action, notamment au travers de l'idée de citoyenneté écologique. Cet entretien permet de (re)découvrir à travers Andrew Dobson tout un pan des recherches conduites dans le monde anglo-saxon sur l'environnement et la politique, qui font écho aux préoccupations et centres d'intérêt structurants de NSS et qui ouvrent des perspectives très stimulantes pour penser comme pour agir.

La Rédaction

\section{A specific view on politics: emergence and structuring of green political theory}

NSS: Andrew Dobson, how did you get involved in the beginning of what would later be called green political theory?

Andrew Dobson: My first involvement with green political theory, when it probably didn't even have a name at that time, was in the mid-1980s. And my first encounter with this whole field was actually through what we would now call environmental philosophy - in particular theories around deep ecology. I came across a Radical Philosophy journal which printed a series of articles by some of the early North American theorists around deep ecology, and I was completely entranced and surprised by these texts. Because of what it was demanding

Auteur correspondant: L. Semal, luc.semal@sciences-po.org of us in an ethical sense. Basically, it was talking about our relationship with the non-human natural world. And I had never really thought of the non-human natural world as part of the political scene - something to be talked about as a political actor or even in terms of an arena, a background against which politics could take place.

So that was new to me and around that time, I was beginning to think about political ideologies in general. I was just starting my academic career. I was teaching political ideologies in Oxford, all the normal ideologies: liberalism, anarchism, Marxism, etc. But I began to wonder why there wasn't a chapter in the ideologies textbooks as it were - on the environment or on ecology. And I began to wonder whether there was an ideology there, so I began to think around whether there might be one and this ended up as my book on Green Political Thought, which was an attempt to describe what I thought was effectively a new political ideology: ecologism. 


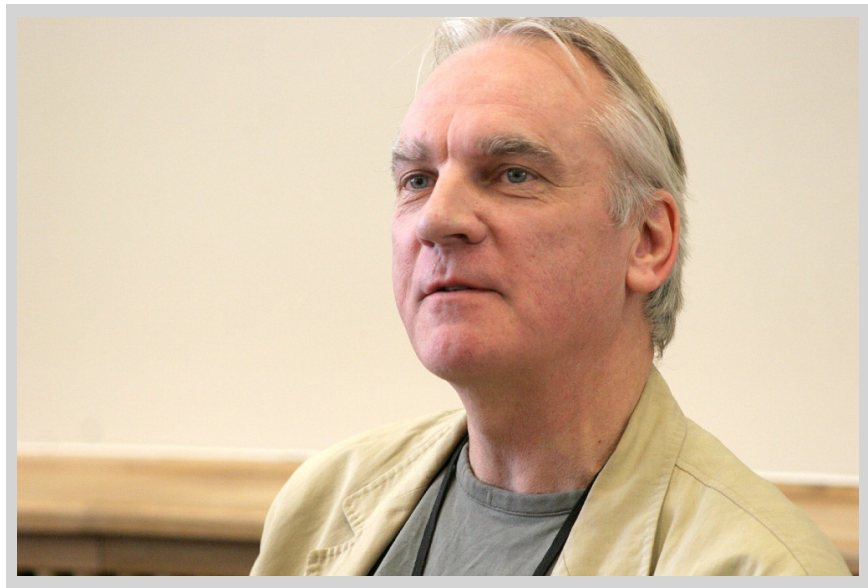

Andrew Dobson (@ altogetherfool sous licence CC BY-SA 2.0).
Andrew Dobson, Professor of Politics at Keele University (UK), is one of the leading figures of green political theory. Green political theory is an area of research developed since the early 1990's in the field of politics, aiming at understanding the ideological and theoretical implications of the arrival of "ecological thought" in politics since the 1970's. Because Andrew Dobson is both an actor in the development of this field and involved in political transformations (he was the lead author of the Green Party's 2010 general election manifesto in UK), it was interesting for NSS to have an exchange with him about the evolution of green political thought, his views on interdisciplinarity and transdisciplinarity issues and the relationships between science and society. The interview was conducted in November 2012.
Around the same time Ibecame aware of people working in Australia or in the United States of America Robyn Eckersley in particular, and Robert Goodin ${ }^{1}$. They were writing, thinking about this topic as well, in a more political way. There was a lot of philosophical work going on at that time around deep ecology and environmental philosophy, but I think myself, Robert Goodin, Robyn Eckersley and others were working more on the politicaltheoretical side of it. So we were thinking about the shape of society, as well as the ethics around engaging with the non-human natural world. At the time then, it was all very disorganised, and there were just various people around the world, working almost at the same time, thinking about the same problematic, and working on it from their own different points of view. And in terms of a core around which people could begin to work, we founded the journal called Environmental Politics, in 1992.

NSS: How did this journal, and maybe other ones, contribute to the organisation of the emerging networks then working on environmental issues?

Andrew Dobson: I remember very well the meeting where we founded it, at the University of Manchester. Michael Waller, Stephen Young and myself had a cup of tea and decided we would found this new journal called Environmental Politics. Michael Waller was already working with a publisher, so he had good contacts in the publishing world, so he persuaded them that we should start this new journal.

To my knowledge, that was the first journal about environment with some politics in it. There had been another journal called Environmental Ethics which had been in existence in America for some time, but it deals pretty much exclusively with environmental philosophy. So I guess our new journal became a point of reference for

\footnotetext{
1 Goodin, R., 1992. Green Political Theory, Cambridge, Polity Press; Eckersley, R., 1992. Environmentalism and Political Theory. Toward an ecocentric approach, London, UCL Press.
}

people who were working on environmental politics, and we understood very broadly the notion of what politics was: it entailed theory, political theory, and some political sociology, some works on political parties and social movements, etc. Then there was one other journal founded in 2000, in North America, called Global Environmental Politics: it deals much more specifically about environmental problems in a global context, so you get a lot of articles on international treaties, climate change, the ozone layer, international environmental NGOs... And there was another environmental philosophy journal founded in 1992, called Environmental Values, which comes out of Scotland and that still exists as well.

So my points of reference in general terms are Environmental Politics, Global Environmental Politics, Environmental Ethics and Environmental Values. For me those are my four main points of reference, and I suppose that amounts to a network for people working on environmental politics.

NSS: Did these journals help to legitimate environmental politics within political science?

Andrew Dobson: Certainly, when we first started, one of the reasons we founded Environmental Politics was because nobody would publish our work. Because environmental politics was not regarded as a legitimate subject - and environmental philosophy, even less so!

But I think that has changed now and it is not so difficult to get one's work published in a mainstream, generic political theory journal for example, or in a mainstream journal dealing with European politics. Now you can get an article on Green parties published in a journal on European politics, whereas 20 years ago it would have probably been quite difficult to do that. I think some people who work in this field, now, almost feel that they should be publishing in those generic journals, in order to try to persuade mainstream political scientists that this is a legitimate subject, which is worth talking about. 
So that is something that has changed over the years. But the four points of reference I mentioned earlier, those four journals, still exist, and people still publish in them very regularly. They are very popular, and there is never any shortage of work anyway to publish in them! In fact, Environmental Politics is now publishing six issues a year. It used to be four, but it is going to six because there is that much work being produced by people.

\section{Specificities of ecologism as an ideology}

NSS: Coming back to green political theory more specifically, how did it happen to emerge within environmental politics?

Andrew Dobson: Let me answer with an anecdote: when I first started teaching environmental politics, I could teach green parties, green sociology, green political theory... everything! Because there was hardly any academic work published on any of it, so within a week you could read everything there was. Whereas now, of course, it has become much more specialised, and you have some specialists on green parties, some on green movements, some on green political theory, and so on. It is very difficult to capture everything - without even talking about ecological economics, or environmental economics, which is another whole topic again.

NSS: And within this growing scientific field of environmental politics, you specialised in green political theory. Could you tell us more about your work on ideologies, and about the distinction you suggest in Green Political Thought, between ecologism and environmentalism?

Andrew Dobson: As I said earlier, the idea of Green Political Thought came up when I was teaching ideologies, and trying to think of what would make ecologism so different to the other ideologies, that it would need a chapter on its own in classical ideologies textbooks ${ }^{2}$.

I could see how a concern for the environment could be spoken in the language of socialism, or conservatism, or liberalism... All those ideologies could talk about the environment, but in a way that would not compromise their core beliefs. However it seemed to me in the mid1980 's, as ecologism was developing in my mind and in the real world, that there was something there that other ideologies could not "swallow" without getting a very severe indigestion: there was something really quite different that made it a new ideology.

So I ended up thinking that the core issues of ecologism are: (1) the limits to growth, which no other ideology can cope with, and certainly no other ideologies had ever

\footnotetext{
2 Dobson, A., 2007 [first ed.: 1990]. Green Political Thought,
} London-New York, Routledge. talked about, and (2) the idea of ecocentrism, or the idea that the non-human natural world has intrinsic value, which is something that no other ideology could conceive of. Other ideologies could deal with the anthropocentric aspects of environmental concern but ecocentrism was much more difficult for them to deal with. Those were the two main developing issues which, if you combined them together and then thought about the kinds of political forms that you would need to deal with them, would make this ideology so different from any of the other ones in the textbook that it needed a chapter on its own.

Environmentalism is kind of a managerial approach to environmental concern, whereas ecologism - as I understood it and as I understand it now still - demands a whole set of changes in the way we organise our societies, the way we think our relationship with the non-human natural world, and in what we can expect from the world in terms of how we live in it. It seems to me that other ideologies, for all their differences, shared a commitment to growth and a commitment to an anthropocentric understanding of what politics is about. So although they are very different, they are similar in those two ways, and those are the two ways in which, I felt, ecologism was so different to them that it really needed to be called an ideology in its own right. I am not sure that everybody would agree with that, but I do think that those are the points of reference around which much of the discussion on ecologism has taken place.

There was also a third pillar of ecologism, although maybe less specific to the ideology, around decentralisation. There was a very big wave of interest in bioregionalism, at one point: again, this mostly came out of North America. The idea was that political forms - spaces, territories - should be dictated by ecological necessities, so people would live with what they have at their disposal in a locality. So you wouldn't be importing kiwi fruits from New Zealand, if they could not grow there, you just wouldn't have them. That would be an ecologist political form, in a sense, dictated by ecological realities.

\section{Evolution of green political theory and its interactions with green realities}

NSS: This idea of dealing with material or ecological realities seem to have always been a core concern for you and other green political theorists?

Andrew Dobson: Yes, I do think that the material issues were there right from the beginning. In fact that was one of the things that I felt about the limits to growth idea, because what really struck me was that that's about as material as you can get. Your politics have to be organised around the planet on which you live and in the recognition that it's finite in size. That was present right from the very beginning. 
However it seems to me that in the 1990s or in the early $21^{\text {st }}$ century, roughly speaking, there was a kind of decline in both the core beliefs in ecologism - the limits to growth on the one hand, and ecocentrism on the other ${ }^{3}$. There was a sort of a sense that neither of those was particularly important any longer. Regarding the limits to growth thesis, it appeared to be under threat as a thesis from "ecological modernisation", which was arguing and still argues that we can get more with less - by being more efficient, by using different kinds of technologies, by being smarter with the ways we act... So ecological modernisers have been arguing that we don't need to worry about limits to growth anymore. And this discourse led to a kind of decline in confidence that the limits to growth thesis actually made sense - and not only in the policymaking community, because it fed back into the academic community as well. That made a big difference to the way in which people began to write and think about environmental or ecological politics.

And at the same time, the ecocentric element to the ideology began to seem less important as well. Perhaps this is where the climate change point comes in, because there was an increasing understanding that yes, the environment is an important issue, but it is important for human beings. And that's enough. Climate change is a problem for human beings and it is such a huge problem that this "ecocentrism stuff" may be just a distraction, that we shouldn't really be thinking about it anymore. So both of those core beliefs in ecologism, as I understood it, came under threat during this period.

NSS: And would you say that this period is over now? That there is a kind of "second wave" of concern for those two core beliefs?

Andrew Dobson: Yes, I do think there's a kind of a second wave coming. We probably are in the middle of it now, and it is a wave that you people are writing about more than $\mathrm{I} \mathrm{am}^{4}$. You are making a big, big difference yourselves in this context, working on peak oil, peak everything issues. Because I think it has brought the whole limits to growth debate back into focus, in a massively important way. So I would say there is a second wave in that sense.

Just in brackets though, I don't see an equivalent return of the ecocentric argument, and that's curious to me. I don't quite know where that went, but I still think that's gone for the moment. I am not sure of what would

\footnotetext{
3 Dobson, A., 2009. "All I left behind" - the mainstreaming of ecologism, Contemporary Political Theory, 8, 3, 319-328.

4 Semal, L., 2012. Militer à l'ombre des catastrophes. Contribution à une théorie politique environnementale au prisme des mobilisations de la décroissance et de la transition. Thèse de doctorat en science politique, Université de Lille 2 ;Szuba, M., 2013. Régimes de justice énergétique, in Sinaï, A. (Ed.), Penser la décroissance. Politiques de l'Anthropocène, Paris, Presses de Sciences Po, 119-137.
}

bring it back either. I think if I wrote Green Political Thought now, it would be a different book, at least regarding the ecocentric issue.

NSS: And what about the third pillar of ecologism, the decentralising idea? Would you say it still remains a core belief?

Andrew Dobson: Yes, I think that this third element would probably be less changed - although this is more modulated now, because that too was challenged in the mid-1990s, mainly by some work that was done around the idea of the Ecostate. People like Robyn Eckersley, John Barry or Marius de Geus argued that if we are seeking real solutions in the real world, an Ecostate would be what we should be heading for ${ }^{5}$. That was accompanied by the climate change issue as well, through the idea that we needed to solve problems globally. So suddenly the nation state and the international arena seemed to be much more important than any elements of decentralisation, and there was also a period when that seemed to disappear too. But again, I would say that is coming back in too again, and I think your work on transition towns is critical here. We're recovering that impulse to decentralisation. That's how I would understand the second wave of ecologism, or the second wave of green political theory.

\section{Confronting mainstream political theory: a paradigmatic quest}

NSS: While listening to you, it seems that it is not enough just to study ecologism as one ideology among others. Do you think that green political theory has a kind of paradigmatic ambition, like ecological economics for example? That it has to challenge mainstream political theory, by confronting it to the ecological challenge?

Andrew Dobson: Well, I suppose so. This may be the name of the game now. I think that green political theory is developing through its encounters with mainstream theory. That's because people in the green political theory current feel, for whatever reason, that they do need to engage with these mainstream currents, rather than maintain some kind of purist isolationism.

NSS: Was it the reason why you and Robyn Eckersley decided to edit the book Political theory and the ecological challenge in 2006 ?

5 Barry, J., 1999. Rethinking green politics, London, Sage; Barry, J., Eckersley, R. (Eds), 2005. The state and the ecological crisis, Cambridge-London, MIT Press; Eckersley, R., 2004. The green State. Rethinking democracy and sovereignty, Cambridge-London, MIT Press; De Geus, M., 1996. The ecological restructuring of the State, in Doherty, B., de Geus, M. (Eds), Democracy and green political thought. Sustainability, rights and citizenship, LondonNew York, Routledge, 188-211. 
Andrew Dobson: What was interesting about the Political theory and the ecological challenge book, I think, was that we decided that we would try to challenge mainstream theorists to think about their mainstream conceptual interests in the light of ecological problems, however they conceive them to be ${ }^{6}$. Can you ignore this new challenge? And if you can't ignore it, what does it do to your views about justice, or liberty, or democracy, or citizenship... What happens to these concepts? And we got people to write about ideologies as well: liberalism, conservatism, socialism... What happens to them in the face of the ecological challenge, as both a theoretical challenge and a real life political challenge? Once climate change appears on the scene, then you inevitably find yourself thinking about that issue in terms of the ideologies that you have at your disposal, and suddenly ecologism is definitely one of them. And I think it does make it more necessary perhaps to rethink all of those concepts and ideologies in these new circumstances: what would they mean? What can they mean? What should they mean, in this new situation?

Probably that book couldn't have been conceived 20 years ago. But when we did conceive it, it had become possible to go to mainstream theorists - like James Sterba, for example, who is a theorist of justice - and say to mainstream theorists who don't really have an interest in environmental problems: "Write us a chapter in a book called Political theory and the ecological challenge". And for them to answer "Oh yes, I know why you want me to do that". That was an unusual and, I think, quite a significant moment in the development of green political theory. It became possible to issue the challenge in a way that mainstream theorists understood that it was a challenge, to which they had to respond.

NSS: This sounds like a big step for green political theory. Is there any risk that it becomes diluted within mainstream political theory?

Andrew Dobson: Maybe there is. When I first started teaching this material, the students found it incredibly exciting, whereas now this has become just another subject among others. When there was no chapter about ecologism in ideologies textbooks, it was something completely new, completely fresh, and the students were astonished: "Deep ecology, this is crazy!" Whereas once it gets into the textbook, it's just another thing to write an essay on and it's another thing to have an examination on... It's been domesticated. It's been tamed to some degree or another.

So, coming back to Political theory and ecological challenge: what effect does it have on green political theory to have it brought into contact with mainstream theory? Is

6 Dobson, A., Eckersley, R. (Eds), 2006. Political theory and the ecological challenge, Cambridge, Cambridge University Press. there a danger that it might become domesticated, tamed, mainstreamed? Maybe there is a possibility that although it was like a courageous and interesting thing to do, the worry might be that green political theory loses some of its integrity, some of its independence by confronting... the mainstream beast, if you like. I don't think that has happened, but I've heard of people worrying about that possibility.

Indeed, there have been some attempts by some people who study ideologies, who try to show that ecologism can be made compatible with the mainstream ideologies, like socialism or liberalism, for example. That's the whole debate around "ecosocialism" or "green liberalism". These are attempts to show that there is enough in the socialist theory, or in the liberal theory and its history, to be able to cope with the ecological challenge. So they meet the kind of demands that political ecologists might have, but in a socialist way or in a liberal way. And that's probably where there have been some major attempts to do what you are suggesting.

However, I do think the challenge is still there. I think it's the other ideologies and the mainstream theorists who remain worried and challenged by this confrontation, just as mainstream economics remain challenged by ecological economics. Because ecological economics maintained its integrity as both a theoretical and a real life challenge, and I think it's very important for us to try to do this with green political theory as well.

NSS: So you think that green political theory, like ecological economics, is maintaining itself as a challenge for mainstream theorists?

Andrew Dobson: Yes, I do. My feeling is that it's maintaining itself, that there is enough integrity, enough difference in its core outlooks and in its core beliefs. And I also think that has been reinforced by peak oil, peak everything, degrowth, transition towns... All those things reinforce that sense of integrity and independence, and otherwise there may have been a danger of disappearing. Ten years ago, maybe I would have been saying something different to what I'm saying now. There is a recovery taking place, which I think is a good thing.

\section{Green political theory and interdisciplinarity: social and natural sciences}

NSS: You mentioned ecological economics as an example to explain what green political theory tries to achieve within political science. Could you tell us more about the links with some other scientific fields, like environmental ethics or environmental history? Did interdisciplinarity have any impact on the emergence of green political theory? 
Andrew Dobson: For me, environmental ethics did make a big impact, but I don't know if everyone would give the same answer. I was also influenced to a certain degree by some works on environmental history, but not to the extent that it made a big difference to me. I became aware of environmental history later, actually. However, when we think about interdisciplinarity, the question is whether we're thinking just within the social sciences, or whether we're talking about interdisciplinarity in a bigger sense, that's to say between the social sciences and the natural sciences.

I first came across the interdisciplinary aspects of green political theory, from a scientific point of view, through John Proops - who is an ecological economist, but who was trained as a physicist and brought that into his economics. He's a big figure in the ecological economics community, and even was the president of the International Society for Ecological Economics in 2002-2003. Well, he taught at Keele University, so he and I used to have lots of conversations, and that's how he began to help me see the importance of interdisciplinarity questions for green political theory. Because as you know, ecologism is one of the few ideologies for which science is really important. Think about climate change: if it's an aspect of the politics, there is a science behind it, and you have to understand it, if you possibly can. I can't think about any other ideology, which needs its science in quite the same way.

So for a student of ideologies, it's very interesting to see that ecologism is one ideology where the natural sciences are really important, as an informing aspect of what the ideology should look like, of what people can say or cannot say. The whole idea of scientific evidence is incredibly important to ecologism as an ideology. And I don't think any other ideology quite has that, so that's absolutely critical. There is, by definition almost, an interdisciplinary demand here. But I think this works both ways: it's not enough to say to me, as a social scientist, "you should learn your science". It is really important for the scientists to learn some social science as well, and actually I'm not sure they always do so. The conversation is not always an easy one, because sometimes there's not a common language. But ideally that's what we would be doing, and that's why we developed a Master's program in Keele, which is an attempt to form students who have a science, and humanities, and some social science understanding of this problem.

\section{Geography and biosecurity}

NSS: You recently co-edited a book about biosecurity, which was written with geographers in an interdisciplinary approach. Could you tell us more about that experience?
Andrew Dobson: Biosecurity is this question about keeping organisms "in the right place", as it were ${ }^{7}$. So it is about disease, pests - whether that disease is transferred among humans or whether that disease can be transferred from animals to humans, and maybe even the other way round. Or diseases that the non-human world, trees and so on, can suffer too. So there are some really interesting questions in biosecurity, which are inevitably, to an extent, political questions - because they are questions about boundaries, and questions about territories. Geography also always talks about boundaries and territories of course, so there is a common language there already among geographers who work on biosecurity and among people who do green political theory or environmental politics of any sort. Because the issue of boundaries and territories comes up all the time, and the additional commonality is that it's about human/nonhuman relationship too. So that's something which geographers who work on this topic have in common again with people who work on green political theory, because they are interested in human/non-human relationship in a very fundamental way.

So I have been organising a two-year long series of five seminars on biosecurity with two younger colleagues who were specialists in the field, and I am definitely not. But I helped them get the grant and we've been running this seminar series, and we published a book in 2013. For me, this has been a very formative experience, engaging with biosecurity specialists, a number of whom were geographers.

One element of it is truly interesting: it is the issue of nativism. In New Zealand for example, they are really keen on keeping their native plants, what they regard as the native plants, and they don't let anything in that is "foreign" or "alien". The language is incredibly interesting here, because you can say things about plants that you would not dare say about human beings, like "Keep the alien plants out!" Of course you couldn't say that about humans being, or at least only from a right-wing point of view. But the whole issue around nativism and naturalness raises the question of what a natural biota truly is: what does it look like? What is native to New Zealand exactly? How do you decide that? And when is your baseline?

Then there are some really interesting issues that come up also around, and maybe this is where the sociologists become interested: in New Zealand, they have some people who are colloquially called "the plant police". And the plant police have a right to come into your garden and look at the plants in it, and if you've got something there that is not native to New Zealand, they can just rip it out

\footnotetext{
7 Dobson, A., Barker, K., Taylor, S.L. (Eds), 2013. Biosecurity. The socio-politics of invasive species and infectious diseases, LondonNew York, Routledge.
} 
and destroy it. In some other parts of the world, that would be regarded as an invasion of privacy, which would be really hard to legitimate, but it's legitimated in New Zealand by this overriding concern to keep the biota intact and native.

Of course this is less of an issue in France or in Britain, but in some countries they seem to take it very seriously. Indeed, New Zealand is a classic example, Australia as well, and then the Galapagos islands... These are classic places where everything must be kept away otherwise the "natural" fauna and flora would be disturbed...

\section{Transdisciplinary programmes}

NSS: So that work about biosecurity is one example of a topic that can surely be treated by green political theory in an interdisciplinary program. But are there some research institutions, which are pushing these kinds of collaboration in the UK?

Andrew Dobson: No, I don't think so. When an interdisciplinary program can be run, it usually happens in a slightly different way.

Let's take a topic like energy, for example: if the government wants to commission some research on energy consumption, the call for proposals will say that any team that applies for money must be of an interdisciplinary sort - otherwise it won't be regarded as a legitimate approach, or a legitimate proposal. So what happens, then, is that interdisciplinary teams are formed. So they do the work on the project that they contracted to work on, but then they probably break up again, once that project is finished. That is quite a common dynamic, based on temporary interdisciplinary teams and not on permanent ones.

But that's not entirely worthless, because these kinds of interdisciplinary teams usually go pretty well, and it's probably because they are problem-focused. They are not coming from a level of theory, they're coming from a pragmatic level: "We have a problem here to solve: how are we going to solve it?" It is often very hard to do interdisciplinary work, because of the lack of a common language, and the conversation is never easy... But it is easier under those circumstances, when a small group is focused on a particular issue. In my experience, that's the worth and the usefulness of those kinds of small, temporary, interdisciplinary teams.

NSS: So there is very little place left for a more ambitious, long-term trandisciplinary approach in the UK?

Andrew Dobson: I suppose so, and that's connected with the way universities themselves in the UK are constructed: they're still very disciplinary bound... In Keele University for example, we had this debate several times, whether the people who are interested in environmental issues should all combine in a new faculty called "Interdisciplinary Environmental Studies" or something like that. But nobody ever wants to do it, and that's probably partly because of how research is evaluated. The way research is measured is very disciplinary focused, so most people are reluctant to move into an interdisciplinary conglomeration, where they may be endangered. That is possibly one of the reasons why they prefer to stay where they are, come together temporarily and move away again. There's a similar problem with research papers as well: when you are thinking about the next evaluation coming out soon, and about what you are going to write and how you are going to write it, you usually don't publish it in some interdisciplinary journal, because no one is going to take it seriously. That's the real problem for this interdisciplinary issue, I think.

\section{Science-society relationships: expertise for public action}

NSS: When you talk about the importance of this interdisciplinary work on environmental issues, it doesn't seem to be just a theoretical challenge for you, but also a real-life challenge. Do green political theorists all share this commitment for greening society?

Andrew Dobson: Of course I don't know for all of them, but I think that for most green political theorists, it's not just an academic interest. They nearly always have a personal interest in those issues of some sort or another, sometimes an activist interest as well. I guess that's true at least in the context of green political theory, and in the context of environmental ethics. Those researchers nearly always have some kind of personal commitment to the principles as well as writing about them. This may be a big difference with other branches of environmental social science, for example the study of green parties. I know people who study green parties who are not interested in green politics at all, in the sense of personal commitment. For them, a green party is just another party. If they want to be good political scientists, they have to study all political parties and so they can't ignore green parties... But they are not really interested in what the greens are saying in any sense of personal commitment.

NSS: So green political theory is not only about describing ideologies, but also about prescribing strategies to change real-life politics?

Andrew Dobson: Yes, it probably is. Nearly all green political theorists would certainly have some sort of sense of commitment to activism, and feel they weren't only describing, but they were prescribing as well. They were writing about it in good faith, but actually they were also engaging in the real world and in politics at the same time. So that's probably a general truth about green political 
theorists, that they are interested in engaging with society too. Of course there may be different ways in which they do that though, because there are many different ways of doing so. There are the normal channels, like working in a green political party. Then there are the extra-parliamentary methods, through working with social movements... And there is also the work you can do with government, through offering advice or consultancy to government departments, for example - trying to work within the system rather than outside of it.

As far as I'm concerned, I have definitely tried to influence decision-making around environmental change, in some way or another - and particularly around behaviour change. I don't really like that term "behaviour change", but let's leave it for the moment. There was an organisation called the Sustainable Development Research Network (SDRN), which still exists, which was funded by the Department of Food and Rural Affairs - so one of the environment-related departments of government in the UK. I was a member of the SDRN for about ten years, and this was a place that had been specifically invented so that academics and policy makers could meet on a regular basis and inform each other. So I was in at the beginning of that, and it was a really interesting experience. We met three or four times a year, and there was a big conference in London every year, where again policy makers and academics would meet and talk during workshops, conferences... So that is one place that was specifically designed to try to bring the academic and the policy community together. I don't know how you measure the success of it, but at the end of my time with the SDRN, I was asked to write a paper on environmental citizenship, because the government was thinking about behaviour change - how best to get people to behave differently.

\section{Environmental citizenship}

NSS: Could you tell us more about environmental citizenship, which is one of your main research topics, and which seems to be a good example of the prescriptive conclusions of green political theory?

Andrew Dobson: Yes... It's interesting that you're putting it like that, because I guess I'm always looking for ways in which the work I do can be translated into something that would be relevant, that would be listened to by policy makers - and that's a challenge, because the kind of work we do is sometimes too... esoteric. Because policymakers want answers all the time, they don't want questions. The last thing a policymaker wants, is another question! But in the end, all we do is ask questions.

So with environmental citizenship, I've tried to present it as an answer to their problem: How to change people's behaviour? How people's behaviour might be changed? Today there are still two dominant policy tools in regard to behaviour change: financial incentives on the one hand, and the "nudges" on the other. Financial incentives are taxations, rewards, fines, etc., which are set up in such a way that people do one thing rather than another: that's a classic policy tool. And the second tool is "nudging", which is officially called "behavioural economics", and which came more recently from North America through a book written by Richard Thaler and Cass Sunstein ${ }^{8}$. In the UK anyway, nudge has become something really important. Seriously, there's like a biblical fervour around the idea of nudge! And it is quite frightening to hear the degree to which this policy tool now dominates thinking around behaviour change in the UK administration...

So the point with environmental citizenship is that it offers an alternative to fiscal incentives and nudging as a way of changing people's behaviour ${ }^{9}$. As I understand environmental citizenship, it's a challenge in a couple of very fundamental ways to these two policy tools. First, it takes into account the fact that people can be otherregarding: in other words, their motivations for actions are not always only self-interested, they can be otherregarding as well. Sometimes people do things because they want to help other people, not because they want to gain some benefit for themselves. And yet, both nudging and fiscal incentives are based only on the self-interested rational animal model of human motivation - so that is one way in which environmental citizenship challenges these other two policy tools. The second way in which it challenges them is in believing that there is such a thing as the common good, or the collective interest, which is something different to the simple addition of people's self-interested motivations and actions. The environmental citizenship view is that there might be a different kind of collective interest, that you only understand when you think about what's good for the community, and not just about what's good for yourself.

So those two things, ability to be other-regarding and to consider a collective interest, you don't find them in fiscal incentives or in nudging. Fiscal incentives and nudging are both based on the basic assumption that people are only motivated by their own short-term self-interest. And they also both assume that you can bring about big change very quickly, almost overnight: if you institute a fine, people want to avoid it tomorrow morning. On the other hand, environmental citizenship is a much longerterm approach to changing people's behaviour: it's quite

\footnotetext{
8 Thaler, R.H., Sunstein, C.R., 2008. Nudge: Improving decisions about health, wealth and happiness, New Haven-London, Yale University Press.

9 Dobson, A., Bell, D. (Eds), 2005. Environmental citizenship, Cambridge-London, MIT Press; Dobson, A., Salz, A.V. (Eds), 2005. Citizenship, environment, economy, London, Routledge.
} 
slow, because it assumes that people can actually learn something, can learn how to be other-regarding and how to consider the collective interest. So basically, environmental citizenship has a kind of moral-ethical underpinning, which is very important to it. It draws on people's capacity for moral and ethically informed action, and that is what differentiates it from financial incentives and nudging. Because my own understanding of sustainability is that it is an ethical and a normative concept, which makes normative and ethical demands upon us. If you don't think about sustainability in a normative and ethical way, you are thinking about it in the wrong way, you're almost making a category mistake... So, environmental citizenship tries to take seriously people's capacity for ethical and morally informed action.

NSS: Did you have any opportunity to talk about environmental citizenship with policymakers, and to see how it could be implemented?

Andrew Dobson: Yes, I wrote a report on environmental citizenship for the SDRN, and during the few months after it was published, I was asked to go and speak to people about it in two particular contexts: energy use and fish discards. First, some people from the Department of Energy asked me to talk to them about environmental citizenship. That was very interesting, because this is quite a high level group of civil servants, who had only been exposed to fiscal incentives and nudging: that was the only tools they knew anything about. And then there was fish discards: that's the fish fishermen throw overboard, because of the rules about what kind of fish and how many you can take back. So they were trying to change people's attitudes to fish eating in the UK: how do you do that? Do you do this through incentives? Do you do it through nudging? Or do you do it through appealing to people's sense of environmental citizenship? Arguing that if we are going to kill fish, we should eat them all rather than just throw them overboard... That we should be thinking in the long term about fish stocks.

NSS: But there may be a fourth possibility to change behaviour, which is using regulatory tools, or legislation. Especially if there is not enough time for environmental citizenship...

Andrew Dobson: Yes, of course. Indeed, time is always the fundamental question. That's one of the big advantages of fines, rewards and taxes: you can change behaviour very quickly. And if we are short of time, then that sounds like the kind of policy that we should be using. And that's probably true for legislation as well: you just make a law and it becomes criminal to do the things you don't want people to do. At the moment, however, the UK government is very interested in a small State, and is ideologically opposed to making environmental laws... So it is less inclined to go down this kind of route, and that's why it is so interested in nudging and financial incentives. But you are right to say that in other contexts, legislation is definitely a fourth option, and a really important one.

By the way, it's the idea that lies behind the concept of Ecostate: trying to use the State itself as a tool, for pushing regulations and making society moving in a different, sustainable direction. Of course, that may be quicker than environmental citizenship. However, I'm in two minds about this. I understand that we are in a hurry, but if you hurry in the wrong direction, you won't get to the right place. You may actually end up in the wrong place quicker, but in the wrong place.

NSS: So environmental citizenship challenges the idea that we should quickly enforce people to change their behaviour whether they agree or not?

Andrew Dobson: Yes, it does. After the first Limits to growth report in 1972, there was a lot of thinking in that way. William Ophuls, for example, was arguing in exactly that way, even if his latest work is much less dramatic and much less anti-democratic than it was in the mid-1970's ${ }^{10}$. Anyway, there was definitely a trend in that direction in the mid-seventies, and if you follow that direction you end up with a kind of green Leviathan, or a benign green dictatorship, or something of this sort. But my feeling is that you have to take people with you, because without them you can't have any long-term settlement or long-term behaviour change. So that's why I think you need both ecology and democracy, rather than either one or the other.

I also agree that the main challenge to that view is the one of time. Maybe we don't have time for mobilising civil society around those issues. But anyway, I don't see any change possibly happening unless civil society really gets up, acts together, and influences both the State and the market. Civil society is where I think the action needs to be, where there may be the source of change. And if it doesn't come from there, then we are not going to get it at all. That's the danger, that we don't get it at all.

\section{Perspectives for the development of green political theory}

NSS: If there is a danger, how do you think green political theory can contribute to find solutions when confronted to the ecological challenge? What does it add to classic, mainstream political theory? What does it bring that is really specific?

Andrew Dobson: Well, I'll end up going back to what I said at the beginning of the interview really, which are these two main differences that distinguishes ecologism

\footnotetext{
${ }^{10}$ Ophuls, W., Boyan, A.S. Jr., 1992 [first ed.: 1977]. Ecology and the politics of scarcity revisited. The unravelling of the American dream, New York, W.H. Freeman and Company.
} 
from the other ideologies: green political theory brings into view the limits to growth idea and the potential ecocentrism. When you bring those two points of reference into contact with some of the concepts in mainstream political theory, they are challenges to those concepts: what does sovereignty mean if there really are limits to growth? What does citizenship mean? What happens to freedom? To democracy? To equality? To the State? What happens to all those concepts in political theory when they are challenged by those two key green issues? It's almost like any of those classic concepts looks different from the point of view of limits to growth and nonanthropocentrism.

Possibly the area where the conversation has been most fruitful is in the context of justice. A lot of work has taken place there, and within that debate, the most interesting area is the question of the community of justice: who should be a member of the community of justice? Traditional political theory would assume that present generation human beings constitute completely the community of justice. But when you start thinking about it from a green political theory point of view, you start thinking for example about future generations of human beings, which again traditional theories of justice had never done - with one or two small exceptions, but traditionally it has only been about present generations of humans. And of course, it brings with it the question of whether non-human animals should also be potential recipients of justice, or not. Not just charity, but justice. So, there is a more specific example of what can happen to a concept when it's confronted by green political theory.

NSS: So despite the relative mainstreaming of ecologism, those two ideas - limits to growth and ecocentrism remain the core epistemological challenges raised by green political theory?

Andrew Dobson: Yes, I think so. What is interesting to me, about peak oil and peak everything, is that it has allowed a kind of a new flourishing of the limits to growth idea - in a different context, but the same kind of idea that there was 40 years ago.

Now, what would be really interesting would be a Renaissance of that ecocentric impulse, which I still think was really powerful in the late 1980's. But I don't see much sign of it, and I don't know where it would come from.
Take climate change: now it's almost entirely an anthropocentric concern, which is weird in a way, because we know that climate change would affect non-human animals as well. Some will be wiped out, some will be unable to move further than they already do, etc. I am sure that 30 or 40 years ago, the non-human element of this would have been really important in a green perspective, but it doesn't seem to be so important now. And that's true as well for the ecosystem services and for peak oil, which are nowadays very anthropocentric concerns.

NSS: And in the longer term, do you think that green political theory could contribute to rethink political theory in the coming context of global resource depletions?

Andrew Dobson: Well, that's exactly what William Ophuls tried to do in his book: to grapple with the implications of scarcity in politics. Not a temporary scarcity, which you can see the end of, but more an absolute scarcity... And that's something completely different. So he's talking about a situation in which the circumstances of politics are completely different to the ones we had for the last three or four hundred years. He talks about the last 400 years as being an exception in human history, but an exception that's coming to an end. Fossil resources were like a subsidy from the past, which we've exhausted. His view is that we probably will go back to something like the politics of the pre-boom era, to the politics of the seventeenth century, the Hobbesian state of nature. And he's got quite a pessimistic view of what's going to happen. It's not quite as bad as in Cormac McCarthy's The Road, but it's that sort of question: what happens to politics under conditions of scarcity? What happens when you can't promise people that they will have more in the future than they've got now? That's exactly his question. I don't think that many theorists are thinking about politics in that way, but we absolutely need to. That may be the critical task of political theory now: to think that through.

\section{Acknowledgments}

Thanks to Léa Bouguyon, Marie Drique, Mathilde Vervynck and Tiphaine Burban for their precious help in the transcript of the interview. 